\title{
Language Assessment Literacy Level of EFL Teachers: A Focus on Writing and Speaking Assessment Knowledge of the Teachers
}
Eda GENÇ⿻
Hacer ÇALIŞKAN**
Doğan YÜKSEL**

\begin{abstract}
This study aims to explore Language Assessment Knowledge (LAK) level of high school EFL teachers in terms of assessment of writing and speaking. In addition, another purpose of this study is to investigate whether there is any significant effect of some demographic variables (years of teaching experience, type of undergraduate degree, attending a training course) on teachers' assessment of writing and speaking knowledge. The previous studies focus on university or primary school context in Turkey; however, there is no study which gave place to the high school context. The study was conducted among 58 high school EFL teachers in Turkey. A demographic questionnaire with 8 questions was used for collecting certain demographic information about the teachers. Language Assessment Knowledge Scale (LAKS) which is comprised of 30 items and 2 dimensions (writing and speaking) was used for gathering the data. The data was analysed through Two-Way Multivariate Analysis of Variance (MANOVA). The results demonstrated that the teachers have high literacy knowledge in one of the sub-component fields while they have low literacy knowledge in the other field.
\end{abstract}

Keywords: Language Assessment Knowledge (LAK); Language Assessment Knowledge Scale (LAKS); skill-based language assessment; assessment ofwriting; assessment of speaking.

\footnotetext{
* Orcid ID: https://orcid.org/0000-0002-8881-9445, Turkey, edagenc123@gmail.com

${ }^{* *}$ Orcid ID: https://orcid.org/0000-0002-6861-8021, Turkey, hacerkanbur@gmail.com

*** Orcid ID: https://orcid.org/0000-0001-9131-3907, Assoc. Prof. Dr., Kocaeli University, Turkey, doganyuksel@gmail.com
}

Genç, E., Çalışkan, H. ve Yüksel, D.. (2020). Language assessment literacy level of efl teachers: a focus on writing and speaking assessment knowledge of the teachers. Sakarya University Journal of Education, 10(2), 274-291. doi: https://doi.org/10.19126/suje.626156 


\section{INTRODUCTION}

Assessment is an instrumental function of teaching-learning process. While assessment is vital to evaluate the students' progress, the concerns about whether the instructors have the necessary assessment literacy should be taken into consideration for an effective assessment process.

Assessment has gained greater attention through some internal and external motivations that have taken place in the first decade of $21^{\text {st }}$ century (Fulcher, 2012). With respect to the external reasons, the legislation of No Child Left Behind from the United States and Common European Framework of References from the European Union are milestones for assessment policy, which are closely related to and followed by English Language Teaching programs in Turkey, as well. English language teachers' understanding of the importance of assessment in the language learning process is interpreted as the internal reason for the language assessment's gaining popularity (Fulcher, 2012).

While language assessment has attracted the attention of practitioners and scholars, the amount of time and space allocated to the process of assessment remains inadequate (Hatipoglu, 2015). One of the most fundamental stages of a lesson is the assessment part, which shapes learners and teachers, also the way teachers employ at the time of teaching. Teachers need to have language assessment literacy to measure student performance and to guide them for further learning processes (Malone, 2011; Tsagari \& Vogt, 2017). There are two specific courses associated with assessment in English Language Teaching departments in Turkey; that is, Assessment and Evaluation course and English Language Testing and Evaluation course. Assessment and Evaluation course is generally taught in students' native language and addressed to all students of Education Faculty, not just for English Language Teaching Department's students. Also, it covers more general topics related to testing. However, English Language Testing and Evaluation course is designed to cover language-related assessment, evaluation, and testing topics. Considering that English Language Testing and Evaluation is the single course throughout one semester in four-year in ELT department, it is hard for the instructors to build on its syllabus (Hatipoglu, 2015; Öz, 2014), meaning that ELT students are less likely to internalize the concepts of assessment.

Depending on the inferences about English Language Testing and Evaluation noted by the authors (Hatipoglu, 2015; Öz, 2014), it is possible that Turkish teachers are not likely to have adequate knowledge in the receptive skills because the undergraduate training does not seem enough to support learners in English Language Testing and Evaluation course. As a result of this, at the time of assessing their students, teachers may not feel selfefficacious about their assessment knowledge. In that sense, for a better teaching and learning process, the greater attention should be paid to assessment issue in Turkish context.

The current study aims to explore the level of language assessment knowledge of teachers in terms of writing and reading. We take into consideration that some features may have an effect on the assessment literacy of teachers. In this point, there is a need for a study 
which should focus on the assessment literacy of English language teachers at high schools.

\section{Assessment Literacy}

Assessment literacy is a teacher's knowledge about how to assess what students have learned and how to implement the data captured by assessment for enhancement of students' learning and his teaching approach (Webb, 2002). In addition to theoretical knowledge, a teacher should know how to ensure the reliability and validity of assessment tool and should be aware of the procedures and concept that influence the process of assessment (Popham, 2011). In a practical aspect, a teacher should collaborate with his/her colleagues to design an assessment process which influences directly what students are going to learn (Braney, 2011). Assessment literacy requires teachersbe aware of both theoretical and practical dimensions of assessment and evaluation (Yastıbaş, 2018). Besides, it demonstrates to what extent a teacher can reflect his assessment knowledge through different approaches and in a different context.

Fulcher (2012) made a definition of assessment literacy after a study conducted to investigate the assessment practices needs of language teachers. He claims that assessment literacy has three aspects. The first one is the ability to design, improve, preserve or evaluate standardized tests. The second one is awareness of assessment process, concepts, and principles that guide to practice. The last one is the ability to integrate knowledge, processes, and concepts in a social and philosophical frame to understand why assessment practices have arisen, what the role of assessment is, and what the effect of assessment on classroom and individuals is.

Newsfield (2006) defines assessment literacy from a different point of view. He categorizes assessment literacy from the viewpoint of a professional test developer, a university student, and a high school teacher. For professional test developers, each part of their work is related to assessment literacy. For a university student, assessment literacy is the knowledge of how successfully he/she acts during exams. For a teacher, it is the ability to grade students correctly and ethically.

As it was understood from different views of scholars, the definitions of assessment literacy vary depending on the context of use (Pill \& Harding, 2013), however, we can grasp the common view of which teachers should understand all different purposes of assessment and use them appropriately (Volante \& Fazio, 2007).

When we have a look at why assessment literacy is important, various aspects of teaching like making decisions for large group instructions and developing instructional programs are affected by assessment inevitably (Mertler, 2003). Therefore, it is significant for teachers to be expert in assessment literacy to shape the instructions and to develop the students' learning (White, 2009). Supportingly, Stiggins (1991) argues that teachers should have adequate classroom assessment data to make decisions about their students' learning development by convenient instruction and at the last step, to make the most benefit from these decisions. If teachers cannot have knowledge about the effectiveness of his/her instruction and make changes for the achievement of the students, the students 
may come across long-lasting bad effects and they may not have an idea about their own learning process (White, 2009).

\section{Language Assessment Literacy}

Language Assessment Literacy (LAL) is the ability of a language teacher which is essential for understanding, analyzing, and using students' assessment data for the enhancement of their learning. (Inbar - Lourie, 2008). It is the knowledge of a language teacher through which the teacher evaluates his/her assessment in classroom (Fulcher, 2012). In other words, it is the ability to both develop and evaluate tests and other assessment components in detail and to evaluate grade assessment by theoretical knowledge (Vogt \& Tsagari, 2014). According to Fulcher (2012), language assessment literacy also includes comprehending historical and political aspects for explaining how assessment may influence individuals.

When we have a look at why language assessment literacy is important, it affects teachers' practices and the students' learning development. Thus, the integration of language teaching with language assessment help students improve their learning (Malone, 2011; Rea-Dickins, 2004). Rea-Dickins (2004) stated that activities that language teachers use during language assessment are significant because the teachers have the opportunity to observe their students through these activities. The observation through the activities includes an assessment of the students' performances with different methods. The data obtained by this observation enables teachers to make decisions for their instructions and the learning process of students.

Language assessment literacy has gained significance in recent years, and a growing literature deals with this field nowadays (Yastıbaş, 2018). Although it is a new field (Fulcher,2012), there is a growing demand for language assessment literacy of language teachers and there are many studies on assessment literacy (Ölmezer-Öztürk \& Aydin, 2018).

Different researchers conducted studies about different aspects of the field around the world. Some studies focused on teachers' assessment knowledge and its effect on assessment procedure when we look at the international sphere. In the study of Kiomrs, Abdolmehdi and Naser (2011), it was found that Iranian EFL teachers have poor knowledge of language assessment, so they use standardized tests as they only know them as sources for assessment. Their exams were a copy of a standardized test with or without change. The researchers of the study believe that the participants could not find any resolution for the washback effect of the standardized tests on students because of poor knowledge about assessment. In a similar study, Xu and Brown (2017) found that language assessment literacy of teachers at Chinese universities is low; their pre-service and in-service teacher training is inadequate so they use standardized tests.

In other studies, the focus is on teacher training. Tsagari and Vogt (2017) conducted a study to investigate teachers' perceived level of language assessment literacy and their training needs for language assessment in seven different European countries. It was concluded that language teachers did not have adequate assessment literacy training 
except some areas like purposes of testing, external tests, and exams. The case of insufficient training causes teachers to conduct assessment tools inappropriately in their classrooms, and to gain negative experiences.

The studies about language assessment literacy in Turkey are inefficient and inadequate to gain a comprehensive view of the field in the country. Hatipoğlu (2015) studied for investigation about the knowledge of pre-service English language teachers in Turkey and their expectations for the content of related course and methodology. The study revealed that few teachers are ready to face challenges emerged through classroom assessment as they haven't accessed the opportunity to learn to do so. Also, it was concluded that the local context and the students' prior experience affect their beliefs about assessment. Similarly, Mede and Atay (2017) explored the assessment literacy of English teachers at preparatory schools in foundation universities in Turkey. In the study, it was revealed that Turkish EFL teachers' language assessment and testing literacy is limited. The teachers specifically need classroom-based assessment training and need knowledge about content and concepts about assessment. For example, the participant teachers are lack of adequate knowledge about test preparation and providing feedback.

\section{Teachers' Perceptions and Practices in Language Assessment}

According to Scarino (2013), in addition to knowledge, ability, and principles, it is important to take into account the teachers' interpretive structures as language teachers have specific teaching context, perceptions, beliefs, and practices all of which shape their own language assessment literacy.

Shim (2009) searched for teachers' perceptions and practices for English language assessment. In this study, the results demonstrated that teachers have sufficient assessment literacy and they are concerned with assessment principals. Although they have adequate assessment literacy, they do not use these principals in their classrooms. The teachers sometimes have no control of the assessment process as they have overcrowded classrooms and heavy teaching burdens.

In the study of Öz and Atay (2017), teachers' perceptions and the relationship between their perceptions and experiences were investigated in Turkey. In the study, twelve prepschool teachers were interviewed and it was concluded that teachers have adequate classroom language assessment knowledge; however, their practices do not reflect their knowledge. Also, it was found that there is no relationship between their practices and experiences. In a similar study by Sikka, Nath and Cohen (2007), teachers' beliefs about language assessment were investigated. It was revealed that there is a necessity for different assessment methods in teacher training programs as teachers' beliefs are shaped through their previous knowledge.

In a different study by Munoz, Palacio and Escobar (2012), it was revealed that the participant English teachers believed that assessment could enhance teaching and learning and help evaluate the performance of an institution; therefore, assessment is also important for formative purposes. Despite their beliefs, the participants do not benefit from their assessment results and use their assessment for formative purposes. 


\section{Language Assessment Literacy for Specific Skills}

It can be claimed that the field is inadequate and insufficient in terms of studies about language assessment literacy for reading, writing, listening, and speaking. It is possible to find promising tools and materials for assessment of skills in classrooms; however, it is almost hard to find a study on awareness of teachers about the assessment process. There are few studies on assessment literacy of writing for English as a second language.

Assessment of students' writing skills has a significant role and workload for writing teachers, but studies in assessment literacy of writing areinsufficient (Crusan, Plakan \& Gebril, 2016). In the study of Crusan et al. (2016), the researchers focused on multidimensional factors of assessment of writing, like second language teachers' knowledge, beliefs, practices, and background. The participants were both native and non-native English language writing teachers from 41 countries and the majority of the participants had assessment of writing course before. It was concluded that non-native language teachers were better in assessment of writing and had a higher level of assessment of writing literacy. Also, the result that teachers' beliefs are affected through experience was revealed.

The main purpose of this study is to investigate the assessment of writing and speaking literacy of EFL teachers at high schools in Turkey. We can state that the studies about the field in Turkey are mostly conducted through the participation of pre-service or prep teachers at universities. One another purpose of the study is to investigate whether there is a relationship between the teachers' demographic features and their assessment literacy. So, the study aims to answer the following questions:

1 What are the assessment of writing and speaking literacy levels of EFL teachers at high schools in Turkey?

2 What are the effects of some variables (years of teaching experience, type of undergraduate degree, attending a training course on assessment and testing) on the knowledge in assessment of writing and speaking skills?

\section{METHOD}

\section{Design}

This study employed a quantitative research approach. Of the quantitative research methods, causal-comparative design was utilized since causal-comparative studies explore the already existing causes or consequences of the differences among individuals (Fraenkel \& Wallen, 2006). Accordingly, this study attempts 1) to explore the level of EFL teachers' Language Assessment Knowledge (LAK) in terms of writing and speaking skills and 2) to investigate whether certain categorical variables (years of teaching experience, type of undergraduate degree, attending a training courses on assessment and testing) have a significant effect on the dependent variable (two dimensions of LAK) (see Table 1). 
Table 1

Descriptions of the Variables

\begin{tabular}{ll}
\hline Variables & Descriptions \\
\hline LAKS & Language Assessment Knowledge Scale \\
Gender & $1=$ Female \\
2 & $=$ Male \\
& $1=1-5$ years \\
Years of teaching & $2=6-10$ years \\
experience & $3=11-15$ years \\
& $4=16-20$ years \\
& $5=21$ and above \\
Attending a training on & $1=$ Attending \\
assessment and testing & $2=$ Not attending \\
Type of undergraduate & $1=$ ELT (English Language Teaching) degree \\
degree & $2=$ Non-ELT degrees \\
\hline
\end{tabular}

\section{Participants}

In data collection process, the data were gathered from 58 EFL teachers working at public or private high school across all cities of Turkey. For data collection, clustered sampling method was employed since clustering allows creating multiple clusters of people from a population where they represent homogeneous characteristics and have an equal chance of participation (Fraenkel \& Wallen, 2006).

\section{Data Collection Instrument}

For data collection, Language Assessment Knowledge Scale (LAKS) which was developed by Ölmezer-Öztürk and Aydin (2018) was used. LAKS is originally comprised of 60 items with four dimensions (assessment of writing; assessment of speaking; assessment of reading; assessment of listening). However, within this study, two dimensions (assessment of writing and assessment of speaking) of the LAKS were utilized. The reported Cronbach Alpha reliability scores of the scale are .91 for total scale; for Assessing Writing .49; and .65 for Assessing Speaking. The items of the LAKS were scaled as 1) True, 2) False, and 3) Don't Know. In addition to the LAKS, certain demographic questions were also addressed to the participating teachers. The demographic questions included gender, years of teaching experience, type of undergraduate degree, attending a training course on assessment and testing. 


\section{Data Analysis}

In data analysis, first, the quantitative data were descriptively presented. Later, to examine the effect of certain background variables on two dimensions of the LAKS, the data was analysed through Two-Way Multivariate Analysis of Variance (MANOVA) since more than one dependent variable (two dimensions of LAKS) requires multivariate analysis (Tabachnick, Fidell \& Ullman, 2007).

\section{FINDINGS}

\section{Research Question 1}

What is the skill-based Language Assessment Knowledge (LAK) level of EFL teachers in Turkish education setting?

In order to understand EFL teachers' LAK level, the gathered data were analysed through descriptive statistics. As displayed in Table 2, the results indicated that the mean score of participants in LAK-writing is 7.33 out of 15 . In particular, the number of items answered correctly by the respondents is almost half of the total correct score, which can be taken in this dimension. This means that the knowledge of the participants in writingassessment is slightly lower than $50 \%$. In addition, the lowest mean score $(M=.14)$ for this dimension is observed for the item 7 "Giving learners an opinion and asking them to discuss it is a valid way of assessing their writing skills." While the highest mean score (M $=.78$ ) of writing-assessment is reported for the item 2 "Analytic scoring is used to see the strengths and weaknesses of learners."

Table 2

Skill-based LAK level of EFL teachers in Turkish education context

\begin{tabular}{lllllll}
\hline Items & $N$ & True & False & Don't & Mean & SD \\
Know & & &
\end{tabular}

Assessing Writing (Bold ones refer to the participants with correct answers)

\begin{tabular}{|c|c|c|c|c|c|c|}
\hline $\begin{array}{l}\text { 1. Giving two options to learners and asking } \\
\text { them to write about one ensure reliable and } \\
\text { valid scoring. }\end{array}$ & 58 & 34 & 15 & 9 & 26 & ,44 \\
\hline $\begin{array}{l}\text { 2. Analytic scoring is used to see the } \\
\text { strengths and weaknesses of learners. }\end{array}$ & 58 & 45 & 5 & 8 & 78 & ,42 \\
\hline $\begin{array}{l}\text { 3. The parts of a scoring scale and the scores } \\
\text { in each part do not change for different } \\
\text { levels of learners. }\end{array}$ & 58 & 15 & 41 & 2 & 71 & ,45 \\
\hline
\end{tabular}


4. When there is a disagreement between the scores of the two raters, they score the written work again.

5. Learners are required to write about at least two tasks in the exam rather than one task.

6. Giving restrictive prompts/guidelines to learners for the writing task is avoided.

7. Giving learners an opinion and asking them to discuss it is a valid way of assessing their writing skills.

8. Using visuals which guide learners for writing poses a problem.

9. Holistic scoring is used to see whether the learner is proficient or not at the end of the term.

10. Analytic scoring leads to greater reliability than holistic scoring in writing.

11. In controlled writing, learners have the chance to convey new information.

12. Classroom evaluation of learning in terms of writing is best served through analytic scoring rather than holistic scoring.

13. Irrelevant ideas are ignored in the assessment of initial stages of a written work in process writing.

14. Providing a reading text for writing is a way of assessing writing skills.

15. Mechanical errors (e.g. spelling and punctuation) are dealt with in the assessment of later stages of a written work.

$\begin{array}{llllll}58 & 38 & 9 & 11 & , 16 & , 36\end{array}$

$\begin{array}{llllll}58 & 30 & 16 & 12 & , 52\end{array}$

$\begin{array}{llllll}58 & 26 & 23 & 9 & 40 & 49\end{array}$

$\begin{array}{llllll}58 & 48 & 8 & 2 & , 34\end{array}$

$\begin{array}{llllll}58 & 15 & 35 & 8 & , 60 & 49\end{array}$

$\begin{array}{llllll}58 & 30 & 10 & 18 & , 52\end{array}$

$\begin{array}{llllll}58 & 25 & 9 & 24 & 43\end{array}$

$\begin{array}{llllll}58 & 18 & \mathbf{2 8} & 12 & , 48\end{array}$

$\begin{array}{llllll}58 & 33 & 8 & 17 & , 56\end{array}$

$\begin{array}{llllll}58 & 28 & 17 & 13 & , 29\end{array}$

$\begin{array}{llllll}58 & 43 & 9 & 6 & , 74\end{array}$

$\begin{array}{llllll}58 & 41 & 11 & 6 & , 71\end{array}$ 


\section{Assessing Speaking}

16. When the interlocutor does not

$58 \quad 30$

22

,38

, 48 understand the learner, giving that feeling or saying it poses a problem.

$\begin{array}{lllllll}\text { 17. Giving learners one task is enough to } & 58 & 9 & 44 & 5 & \text {, 76 }\end{array}$ assess speaking skills.

$\begin{array}{lllllll}\text { 18. Interlocutors' showing interest by verbal } & 58 & 11 & \mathbf{4 1} & 6 & \text {, 71 }\end{array}$ and non-verbal signals poses a problem.

19. When it becomes apparent that the learner cannot reach the criterion level, the task is ended.

20. Using holistic and analytic scales at the same time poses a problem.

21. Reading aloud is a technique used to assess speaking skills.

22. In interlocutor-learner interviews, the teacher has the chance to adapt the questions being asked.

23. In interactive tasks, more than two learners pose a problem.

24. The interlocutor gives the score when the learner is in the exam room.

25. In a speaking exam, production and comprehension are assessed together.

26. Asking learners to repeat a word, phrase or a sentence is a way of assessing speaking skills.

27. Discussion among learners is a way of assessing speaking skills.

28. A checklist is a means of scoring oral presentations in in-class assessment.

29 . When the focus is to assess discourse, $\begin{array}{llllll}58 & 28 & 25 & 5 & , 48\end{array}$ $\begin{array}{llllll}58 & 16 & 18 & 24 & , 31\end{array}$ $\begin{array}{llllll}58 & 20 & 36 & 2 & , 34\end{array}$ $\begin{array}{llllll}58 & 46 & 3 & 9 & , 79\end{array}$ role plays are used.

30. In peer interaction, random matching is avoided.

$\begin{array}{llllll}58 & 25 & 28 & 5 & , 43\end{array}$

$\begin{array}{llllll}58 & 20 & 33 & 5 & , 57\end{array}$

$\begin{array}{llllll}58 & \mathbf{5 0} & 4 & 4 & , 86\end{array}$

$\begin{array}{llllll}58 & 29 & 24 & 5 & , 50\end{array}$

$\begin{array}{llllll}58 & 54 & 1 & 3 & , 93\end{array}$

$\begin{array}{llllll}58 & \mathbf{5 0} & 2 & 6 & , 86\end{array}$

$\begin{array}{llllll}58 & 45 & 6 & 7 & , 78\end{array}$

$\begin{array}{llllll}58 & 17 & 27 & 14 & , 29\end{array}$




\begin{tabular}{lccc}
\hline Speaking-Total & 58 & 8,99 & 6,47 \\
\hline $\begin{array}{l}\text { LAKS-Total (including only speaking and } \\
\text { writing) }\end{array}$ & 58 & 16,29 & \\
\hline
\end{tabular}

Regarding the assessment of speaking dimension in LAK, the results indicated that the total mean score of the participants is 8,99 out of 15 , indicating that the performance of the participating teachers is over the average score in assessment of speaking. For the total scale, the mean score of the participants is 16, 29 out of 30, which means that the teachers performed over average score (15) in LAK (writing and speaking). Moreover, the lowest mean score $(\mathrm{M}=.29)$ for speaking-assessment dimension is observed for the item 30 "In peer interaction, random matching is avoided; on the other hand, the highest mean score $(M=.93)$ of speaking-assessment is reported for the item 27 "Discussion among learners is a way of assessing speaking skills."

While the reported mean scores of each dimension provide an idea about the performance of teachers, the question of whether the values between the average point and the observed means create a significant difference should be explored. To this end, onesample t-test was conducted to see whether the reported values significantly differ from the average scores. In particular, the obtained mean scores for each dimension (writing and speaking) and the total LAK were compared with the average score of each dimension (7.5 out of 15) and the total LAK (15 out of 30) in order to explore whether the performance of the participants were significantly different from the cut-off average values, indicating a degree of performance for the particular skill.

Table 3

One Sample t-test results-skill based

\begin{tabular}{lcccc}
\hline Skills & Mean Diff. & $\mathrm{df}$ & $\mathrm{t}$ & $\mathrm{p}$ \\
\hline Assessing Writing &,- 17 & 57 & $-5,07$ & $.00^{*}$ \\
Assessing Speaking & 1,49 & 57 & 3,22 & $.00^{*}$ \\
Total LAK & 1,29 & 57 & 1,29 & $.00^{*}$ \\
\hline${ }^{*}<<05$ & & & &
\end{tabular}

${ }^{*} \mathrm{p}<.05$

As displayed in Table 3, the results indicated that the mean difference $(M=1,29)$ between the respondents' LAK performance $(M=16,29)$ and the maximum average mean score (M = 15) statistically differed, which means that the participants' total LAK is significantly higher than the average score. In particular, the EFL teachers performed better in the total LAK. When it comes to the writing skill, the mean difference $(M=-, 17)$ between the 
respondents' writing performance $(\mathrm{M}=7,33)$ and the maximum average mean score $(\mathrm{M}$ $=7,5$ ) statistically differed, which means that participants' level of writing skill is significantly lower than the average score. In other words, the participating EFL teachers performed under the average score in writing dimension.

On the other hand, the mean score difference $(M=1,49)$ between the respondents' speaking performance $(M=8,99)$ and the maximum average mean score $(M=7,5)$ statistically differed, which means that participants' level of speaking skill is significantly higher than the average score. In other words, the EFL teachers performed above the average score in assessment of speaking dimension.

\section{Research Question 2}

What are the effects of certain background variables (years of teaching experience, type of undergraduate degree, attending a training course on assessment and testing) on the LAK level of EFL teachers regarding assessment of writing and assessment of speaking?

In order to explore the effects of the selected variables on the dependent variable, three separate MANOVAs were performed. First, the effect of years of teaching experience (1-5 years; 6-10 years; $11-15$ years; $16-20$ years; and 21 years and above) on LAK dimensions (assessment of writing and speaking) was analysed. As shown in Table 4, the level of EFL teachers' Language Assessment Knowledge (LAK) does not significantly differ by the years of experience, which means that the experience of EFL teachers has no meaningful effect on the dimensions of Language Assessment Knowledge (LAK).

Table 4

Language Assessment Knowledge by Years of Teaching Experience

\begin{tabular}{lccccc}
\hline & Sum of Squares & $\mathrm{df}$ & Mean Square & $\mathrm{F}$ & $\mathrm{p}$ \\
\hline Between Groups & .10 & 4 & .03 & 1,97 & .11 \\
Within Groups & .68 & 53 & .01 & & \\
Total & .78 & 57 & & & \\
$\mathrm{p}<.05$ & & & & &
\end{tabular}

Second, the effect of undergraduate degree type (ELT or Non-ELT) on the LAK dimensions was examined. As displayed in Table 5, the level of EFL teachers' Language Assessment Knowledge (LAK) did not significantly differ by the type of undergraduate degree, which means that the programme (either ELT or Non-ELT) being graduated for EFL teachers has no meaningful effect on the Language Assessment Knowledge (LAK) 
Table 5

Language Assessment Knowledge by Type of Undergraduate Degree

\begin{tabular}{lccccc}
\hline & Sum of Squares & $\mathrm{df}$ & Mean Square & $\mathrm{F}$ & $\mathrm{p}$ \\
\hline Between Groups & .00 & 1 & .01 & .33 & .57 \\
Within Groups & .77 & 56 & .01 & & \\
Total & .78 & 57 & & & \\
\hline
\end{tabular}

Lastly, the effect of attendance in training course for testing and assessment on the LAK dimensions was explored. To the results of the analysis, as depicted in Table 6, the level of EFL teachers' Language Assessment Knowledge (LAK) does not significantly differ by the attendance of EFL teachers to training on testing and assessment, which means that attending training on testing and assessment among EFL teachers has no meaningful effect on the Language Assessment Knowledge (LAK).

Table 6

Language Assessment Knowledge by attending training on testing and assessment

\begin{tabular}{lccccc}
\hline & $\begin{array}{c}\text { Sum of } \\
\text { Squares }\end{array}$ & $\mathrm{df}$ & Mean Square & $\mathrm{F}$ & $\mathrm{p}$ \\
\hline $\begin{array}{l}\text { Between } \\
\text { Groups }\end{array}$ & .00 & 1 & .00 & .61 & .44 \\
Within & .77 & 56 & .01 & & \\
Groups & .78 & 57 & & & \\
Total & & & & & \\
\hline
\end{tabular}

\section{DISCUSSIONS AND SUGGESTIONS}

The first aim of the study was to find out the language assessment knowledge level of the participant teachers regarding two skills that are writing and speaking. It was found that assessment of writing knowledge of the participants was lower than the average. The highest mean score belongs to the item 2; "Analytic scoring is used to see the strengths and weaknesses of learners" the answer to which is true. This mostly preferred item confirms East's (2009) argument that analytic scoring, due to its various features, is more reliable and objective than a holistic one. Analytic scoring can be held if the aim is to gather 
diagnostic results from the test (Bachman \& Palmer, 1996; Brown, 2003; Hughes, 1989). The diagnostic data tell the teachers about the learners' strengths and weaknesses (Huot, 1996; Weigle, 2002). It is concluded from the results that most of the EFL teachers at high schools are aware of the features and its benefits which supports the results of ÖlmezerÖztürk's study (2018) which was conducted among EFL university teachers and similar to the findings in the study of Bacha (2001) which concluded that EFL programs benefitted from more analytic measures. The lowest score in assessment of writing part is "Giving learners an opinion and asking them to discuss is a valid way of assessing their writing skills." answer of which is false. This means that teachers are aware of the fact suggested by Harris (1966) and Hughes (1989) that teachers should assess the writing abilities, not the creativity or imagination. This is exactly similar to the study of ÖlmezerÖztürk (2018) in which the same item got the lowest score by the participants. In assessment of speaking part, it was found that the participant teachers' knowledge of assessment of speaking is over the average score. The highest mean score of speakingassessment is reported for the item 27 "Discussion among learners is a way of assessing speaking skills." It means that more than half of the participant teachers know that discussion is one of the methods for the assessment of the language learners. This result confirms the views of O'Sullivan (2012) that as learners are required to interact with each other on a given subject, the discussion is a meaningful way to assess the speaking ability. The results of this item are similar to the study of Ölmezer-Öztürk (2018). The lowest mean score for speaking-assessment dimension is observed for the item 30 "In peer interaction, random matching is avoided". This means that most of the participant teachers do not know the fact that the speaker's speech may be affected by the speech, personality or ideas of the other speaker (Hughes, 1989).

In relation to the second research question, the findings revealed that there is no relationship between LAK and all of the specific features of the teachers gathered in the study. In Tao (2014)'s study, it was revealed that there is no relationship between teachers' LAK level and years of experience which is parallel to the present study. The reason for not having any difference between teachers from ELT department and the teachers from other ones may be related to the fact that language assessment is not given priority in ELT programs and there are one or few courses for the field. The fact that the educational background does not affect the level of LAK is parallel to the findings in the study of Tao (2014) and Ölmezer-Öztürk (2018). This result confirms the findings that pre-service education for testing and assessment at state and foundation universities in Turkey is insufficient and the courses are found abstract by the students at universities (Hatipoğlu, 2015; Mede \& Atay, 2017). The findings for the variable of attending to a training course is in contrast with Stiggins (2010) who stated that the reason why teachers are assessment illiterate is lack of professional development programs.

Another purpose of the study was to investigate skill-based (writing and speaking) LAK level. It was found that assessment of writing knowledge is lower than the average; in contrast, speaking ability is higher than the average. In other words, the participant teachers have high assessment of speaking literacy knowledge while they have an 
inadequacy in assessment of writing. Also, there is a positive relationship between writing and assessment of speaking knowledge of the participant teachers. There is no relationship between the teachers' demographic features and their assessment of writing and speaking knowledge.

Depending on the results, it can be suggested that teachers should be given some training courses for the development of their assessment skills. As it was concluded from the study, most of the participants are inadequate in assessment writing. The necessary precautions to solve teachers' needs should be taken.

In the current study, the number of participants may not be sufficient to generalize to a wider context. Also, additional studies can be held with an interview through the participant teachers and it can shed a light on the questions why there is no difference between graduation programs or experience years. An additional study with a triangulation method at high schools may bring a more detailed point of view to the field.

\section{References}

Bacha, N. (2001). Writing evaluation: What can analytic versus holistic essay scoring tell us? System, 29(3), 371-383.

Bachman, L. F., \& Palmer, A. S. (1996). Language testing in practice. Oxford: Oxford University Press.

Braney, B. (2011, April). An examination of fourth-grade teachers' assessment literacy and its relationship to students' reading achievement. Paper presented at the annual meeting of the American Educational Research Association, New Orleans, LA.

Brown, H. D. (2003). Language assessment: Principles and classroom practices. Pearson Education.

Crusan, D., Plakans, L., \& Gebril, A. (2016). Writing assessment literacy: Surveying second language teachers' knowledge, beliefs, and practices. Assessing Writing, 28, 43-56.

East, M. (2009). Evaluating the reliability of a detailed analytic scoring rubric for foreign language writing. Assessing Writing, 14, 88-115.

Fraenkel, J. R., \& Wallen, N. E. (2006). How to design and evaluate research in education. New York: The McGraw-Hill Companies.

Fulcher, G. (2012). Assessment literacy for the language classroom. Language Assessment Quarterly, 9(2), 113-132. doi: 10.1080/15434303.2011.642041

Harris, D. P. (1969). Testing English as a second language. New York: McGraw-Hill.

Hatipoğlu, C.. (2015). English language testing and evaluation (ELTE) training in Turkey: expectations and needs of pre-service English language teachers. ELT Research Journal, 4 (2), 111-128.

Hughes, A. (1989). Testing for language teachers. Cambridge: Cambridge University Press.

Huot, B. (1996). Toward a new theory of writing assessment. College Composition and Communication, 47, 549-566.

Inbar-Lourie, 0. (2008). Constructing a language assessment knowledge base: A focus on language assessment courses. Language Testing, 25(3), 385-402. doi:10.1177/0265532208090158 
Kiomrs, R., Abdolmehdi, R., \& Naser, R. (2011). On the interaction of test washback and teacher assessment literacy: The case of Iranian EFL secondary school teachers. English Language Testing, 4(1), 156-161.

Malone, M. E. (2011). Assessment literacy for language educators. Retrieved from http://www.cal.org/index.php/content/download/1516/15923/file/AssessmentLit eracyforLanguageEducators.pdf

Mede, E., \& Atay, D. (2017). English language teachers' assessment literacy: The Turkish context. Ankara Üniversitesi TÖMER Dil Dergisi, 168(1), 43-60.

Mertler, C. A. (2003, October). Preservice versus inservice teachers' assessment literacy: Does classroom experience make a difference? Paper presented at the annual meeting of the MidWestern Educational Research Association, Columbus, $\mathrm{OH}$.

Munoz, A. P., Palacio, M., \& Escobar, L. (2012). Teachers' beliefs about assessment in an EFL context in Colombia. PROFILE, 14(1), 143-158.

Newfields, T. (2006). Teacher development and assessment literacy. Paper presented at the Proceedings of the 5th Annual JALT Pan-SIG Conference, Shizuoka, Japan (pp. 48-73). Tokai University College of Marine Science.

O'Sullivan, B. (2012) Assessing speaking. In C. Coombe, P. Davidson, B. O'Sullivan, and S. Stoynoff. (Eds.). The Cambridge guide to second language assessment. (pp. 234-246). Cambridge University Press, USA

Ölmezer-Öztürk, E. (2018). Developing and validating language assessment knowledge scale (LAKS) and exploring the assessment knowledge of EFL teachers. Unpublished PhD Dissertation, Anadolu University, Turkey.

Ölmezer-Öztürk, E., \& Aydın, B. (2019). Investigating language assessment knowledge of EFL teachers. Hacettepe Üniversitesi Eğitim Fakültesi Dergisi, 34(3), 602-620. doi: 10.16986/HUJE.2018043465

Öz, H. (2014). Turkish teachers' practices of assessment for learning in the English as a foreign language classroom. Journal of Language Teaching \& Research, 5(4), 775-785.

Öz, S., \& Atay, D. (2017). Turkish EFL instructors in-class language assessment literacy: Perceptions and practices. ELT Research Journal, 6(1), 25-44.

Pill, J., \& Harding, L. (2013). Defining the language assessment literacy gap: Evidence from a parliamentary inquiry. Language Testing, 30(3), 381-402. http://dx.doi.org/10.1177/0265532213480337

Popham, W. J. (2009). Assessment literacy for teachers: Faddish or fundamental? Theory into Practice, 48(1), 4-11. doi: 10.1080/00405840802577536

Rea-Dickins, P. (2004). Understanding teachers as agents of assessment. Language Testing, 21(3), 249-258.

Scarino, A. (2013). Language assessment literacy as selfawareness: Understanding the role of interpretation in assessment and in teacher learning. Language Testing, 30(3), 309-327. https://doi.org/10.1177/0265532213480128.

Shim, K. N. (2009). An investigation into teachers' perceptions of classroom-based assessment of English as a foreign language in Korean primary education. (Unpublished doctoral dissertation). University of Exeter, Exeter. 
Sikka, A., Nath, J. L., \& Cohen, M. D. (2007). Practicing teachers' beliefs and uses of assessment. International Journal of Case Method Research \& Application, 3, 240-253.

Stiggins, R. (1991). Assessment literacy. Phi Delta Kappan, 72, 534-539.

Stiggins, R. J. (2010). Essential formative assessment competencies for teachers and school leaders. In H. L. Andrade, G. J. Cizek (Eds.), Handbook of formative assessment, (pp. 233-250). New York, NY: Taylor and Francis.

Tao, N. (2014). Development and validation of classroom assessment literacy scales: English as a Foreign Language (EFL) teachers in a Cambodian Higher Education Setting. Unpublished PhD dissertation, Victoria University, Australia.

Tsagari, D. \& Vogt, K. (2017). Assessment literacy of foreign language teachers around Europe: Research, challenges and future prospects. Papers in Language Testing and Assessment, 6(1), 41-63.

Tabachnick, B. G., Fidell, L. S., \& Ullman, J. B. (2007). Using multivariate statistics (Vol. 5). Boston, MA: Pearson.

Vogt, K. \& Tsagari, D. (2014). Assessment literacy of foreign language teachers: Findings of a European study. Language Assessment Quarterly, 11, 374-402. doi: $10.1080 / 15434303.2014 .960046$

Volante, L., \& Fazio, X. (2007). Exploring teacher candidates' assessment literacy: Implications for teacher education reform and professional development. Canadian Journal of Education, 30, 749-770.

Webb, N. (2002, April). Assessment literacy in a standards-based education setting. A paper presented at the annual meeting of the American Educational Research Association, New Orleans, Louisiana.

Weigle, S. C. (2002). Assessing writing. Cambridge: Cambridge University Press

White, E. (2009). Are you assessment literate? Some fundamental questions regarding effective classroom-based assessment. OnCUE Journal, 3(1), 3-25.

Xu, Y. \& Brown, G. T. L. (2017). University English teacher assessment literacy: A survey-test report from China. Papers in Language Testing and Assessment, 6(1), 133-158.

Yastıbaş, A. E. (2018). Türk İngilizce okutmanlarının yabancı dilde ölçme değerlendirme okuryazarlığı: Çoklu bir durum çalışması (Unpublished Doctoral Dissertation). Atatürk University, Erzurum. 
In the writing process of the study titled "Language Assessment Literacy Level of EFL Teachers: A Focus on Writing and Speaking Assessment Knowledge of the Teachers", the rules of scientific, ethical and citation were followed; it was undertaken by the authors of this study that no falsification was made on the collected data. "Sakarya University Journal of Education Journal and Editor" had no responsibility for all ethical violations to be encountered, and all responsibility belongs to the authors and that the study was not submitted for evaluation to any other academic publishing environment. 